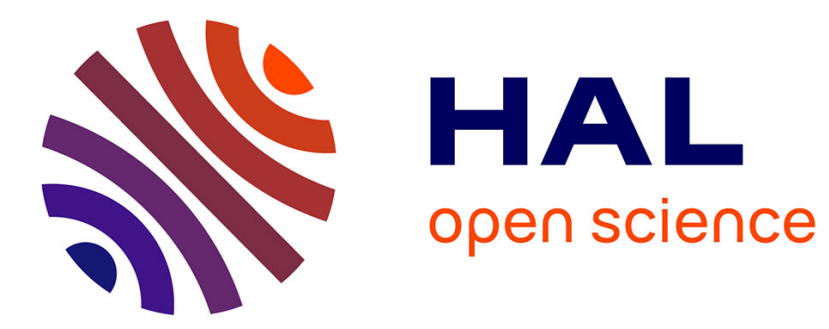

\title{
The Curious Case of Indian Ocean Warming
}

Mathew Koll Roxy, Kapoor Ritika, Pascal Terray, Sébastien Masson

\section{To cite this version:}

Mathew Koll Roxy, Kapoor Ritika, Pascal Terray, Sébastien Masson. The Curious Case of Indian Ocean Warming. Journal of Climate, 2014, 27 (22), pp.8501-8509. 10.1175/JCLI-D-14-00471.1. hal-01141647

\section{HAL Id: hal-01141647 \\ https://hal.science/hal-01141647}

Submitted on 27 May 2016

HAL is a multi-disciplinary open access archive for the deposit and dissemination of scientific research documents, whether they are published or not. The documents may come from teaching and research institutions in France or abroad, or from public or private research centers.
L'archive ouverte pluridisciplinaire HAL, est destinée au dépôt et à la diffusion de documents scientifiques de niveau recherche, publiés ou non, émanant des établissements d'enseignement et de recherche français ou étrangers, des laboratoires publics ou privés. 


\title{
The curious case of Indian Ocean warming
}

\author{
Mathew Koll ROXY ${ }^{1}$, Kapoor RITIKA ${ }^{1,2}$, Pascal TERRAY $^{3,4}$ and Sébastien MASSON $^{3}$ \\ ${ }^{1}$ Centre for Climate Change Research, Indian Institute of Tropical Meteorology, Pune, India \\ ${ }^{2}$ Department of Environmental Sciences, Fergusson College, Pune, India \\ ${ }^{3}$ Sorbonne Universites (UPMC, Univ Paris 06)-CNRS-IRD-MNHN, LOCEAN Laboratory, 4 \\ place Jussieu, F-75005 Paris, France \\ ${ }^{4}$ Indo-French Cell for Water Sciences, IISc-IITM-NIO-IRD Joint International Laboratory, \\ IITM, Pune, India
}

Journal of Climate, Submitted on $2^{\text {nd }}$ July 2014, Revised on 25 Aug 2014

Corresponding author address: Mathew Koll Roxy, Indian Institute of Tropical Meteorology, Pune 411008, India. E-mail: roxy@tropmet.res.in 


\section{Abstract}

2 Recent studies have shown that the central Indian Ocean warm pool has been warming for the

3 past half-century, though the reasons behind this monotonous warming are still debated. The

4 results here reveal a larger picture-that the western tropical Indian Ocean has been warming

5 for more than a century, at a rate faster than any other region of the tropical oceans, and turns

6 out to be the largest contributor to the overall trend in the global mean sea surface

7 temperature (SST). During 1901-2012, the western Indian Ocean experienced anomalous

8 warming of $1.2^{\circ} \mathrm{C}$ in summer SSTs, while rest of the warm pool region went through an

9 increase of $0.7^{\circ} \mathrm{C}$. The warming of the generally cool western Indian Ocean against the rest of

10 the tropical warm pool region displaces the zonal SST gradients, and has the potential to change the Asian monsoon circulation and rainfall, as well as alter the marine food webs in this biologically productive region. The current study using observations and global coupled ocean-atmosphere model simulations gives compelling evidence that, besides direct contribution from greenhouse warming, the long-term warming trend over the western Indian Ocean during boreal summer is highly dependent on the asymmetry in the El Niño Southern Oscillation (ENSO) teleconnection and the positive SST skewness associated with ENSO during recent decades.

\section{Introduction}

A handful of studies have been devoted to the cause and effect of basin-wide Indian Ocean warming (Alory et al. 2007; Chambers et al. 1999; Dong et al. 2014; Du and Xie 2008; Klein et al. 1999; Rao et al. 2012; Swapna et al. 2013); yet the reasons behind the steady and prominent warming remain ambiguous and are still debated. These studies have shown that the whole Indian Ocean has been warming throughout the past half century. A close examination of the sea surface temperatures (SSTs) over the Indian Ocean reveals a larger 
story-that the western Indian Ocean has been warming for more than a century. Figure 1a shows the SST trend during 1901-2012, during northern summer. A striking feature is the absence of any trend in SST over the tropical Pacific, and the presence of a warming trend $\left(>0.1^{\circ} \mathrm{C}\right.$ per decade) over the western tropical Indian Ocean. A similar evolution is found in other seasons and other available SST datasets, though the trend is stronger during summer (Fig.S1).

In comparison with the rest of the Indian Ocean, the western Indian Ocean generally has cooler mean SSTs in summer, owing to the strong monsoon winds and the resultant upwelling over the western Indian Ocean (Fig.2). This creates a zonal SST gradient, which regulates the strength and flow of the moisture laden winds towards the South Asian subcontinent (Izumo et al. 2008; Yang et al. 2007). In addition, the summer SSTs show that western region has the largest interannual variability (Fig.1b). A warming trend in the mean SSTs over this region can in turn modify the monsoon interannual variability (Yang et al. 2007). The western Indian Ocean is also one of the most biologically productive regions during the summer due to the intense upwelling (Ryther and Menzel 1965). Hence a significant change in the SSTs of this region can also alter marine food webs (Behrenfeld et al. 2006). Besides localized responses, a warming in the Indian Ocean has remote influences too. It has been suggested that a warm Indian Ocean has the potential to weaken the El Niño during its developing and terminating phases (Annamalai et al. 2005; Kug and Kang 2006; Luo et al. 2012).

Though earlier studies have investigated the sustained warming over the Indian Ocean, the focus has been on the warm pool region (Dong et al. 2014; Du and Xie 2008; Rao et al. 2012; Swapna et al. 2013). These studies have implied local ocean-atmosphere coupled mechanisms for the continuous warming over the region, in addition to anthropogenic forcing. However, there is large uncertainty among these studies, presenting a chicken-and- 
egg problem on the cause and effect of the warming. Some of these studies argue that the warming weakens the monsoon winds over the Indian Ocean which further enhance the warming, while others suggest that weakened monsoon winds have accelerated the warming (Rao et al. 2012; Swapna et al. 2013).

A few other studies have shown that the SSTs over Indian Ocean are warmer 3-4 months after the mature phase of El Niño (Du et al. 2009; Lau and Nath 2003; Xie et al. 2009). Though a connection between individual El Niños and warm Indian Ocean events has been suggested (Cadet 1985; Murtugudde et al. 2000; Nicholson 1997; Tourre and White 1995; Xie et al. 2002; Yu and Rienecker 1999), no relationship has been demonstrated with respect to the long-term warming trends over the Indian Ocean and hence, its association with El Niño during summer is investigated here.

\section{Data, Model and Methods}

Long-term warming trend and correlations are estimated using SST data for the period 19012012 obtained from the HadISST1 dataset, and robustness of these results are assessed using ERSST and marine-nighttime SSTs from HadMAT (Rayner et al. 2003; Smith et al. 2008). Data coverage in the tropical Indian Ocean is generally quite good since the late $19^{\text {th }}$ century (Compo and Sardeshmukh, 2010; Deser et al., 2010). In order to ascertain the role of greenhouse warming on the Indian Ocean, SSTs from a suite of 25 climate models participating in the Coupled Model Intercomparison Project (CMIP5, Taylor et al. 2012) are used. For examining the atmospheric circulation, the wind and vertical velocity at different levels for the years 1979-2012 are obtained from the ERA interim reanalysis (Dee et al. 2011).

For the numerical model experiments a global coupled ocean-atmosphere model, the SINTEX-F2, which has a realistic simulation of the ENSO-monsoon variability is utilized 
(Masson et al. 2012; Terray et al. 2011). The oceanic and atmospheric components have $0.5^{\circ}$ and $1.125^{\circ}$ horizontal resolution respectively, with 31 levels in the vertical for both. The coupled configuration of SINTEX-F2 is time integrated over a period of 300 years, and utilized as the reference run. In addition, a model sensitivity run is performed over a period of 110 years, by suppressing the SST variability over the Pacific $\left(100^{\circ} \mathrm{E}-70^{\circ} \mathrm{W}, 25^{\circ} \mathrm{S}-25^{\circ} \mathrm{N}\right)$ by a nudging technique. For this experiment, we used the standard configuration of the coupled model without any flux corrections, except in the Pacific where we applied a large feedback value $\left(-2400 \mathrm{Wm}^{-2} \mathrm{~K}^{-1}\right)$ to the surface heat flux. This value corresponds to the 1-day relaxation time for temperature in a 50-m mixed layer. The SST damping is applied towards a daily climatology computed from the reference run. This large correction suppresses the SST variability over the tropical Pacific. Difference between the control and sensitivity runs renders the role of ENSO variability on global climate variability, including its effects on the SST variability over the Indian Ocean.

The unbiased moment estimate of skewness is used to measure the asymmetry, and also the frequency and intensity of ENSO events. This statistic may be computed as Skewness $=n \cdot \mathrm{M}_{3} /\left[(n-1)(n-2) \cdot \sigma^{3}\right]$, where $\mathrm{M}_{3}$ is $\sum\left(\mathrm{x}_{\mathrm{i}^{-}} \overline{\mathrm{x}}\right)^{3}, \sigma$ is the unbiased estimate of standard deviation, and $n$ is the number of observations.

\section{Results}

It is observed that the western Indian Ocean (Fig. $1 \mathrm{c}, 50-65^{\circ} \mathrm{E}, 5^{\circ} \mathrm{S}-10^{\circ} \mathrm{N}$ ) shows continuous warming since the start of $20^{\text {th }}$ century (which attains an increased rate post-1950s), while for the rest of Indian Ocean including the warm pool (Fig.2, SST $>28.0^{\circ} \mathrm{C}$ ) the warming is prominent post-1950s only. At the beginning of the $20^{\text {th }}$ century, the mean summer SST over the western Indian Ocean was around $26.5^{\circ} \mathrm{C}$, which is cooler in comparison to the rest of the Indian Ocean at $27.2^{\circ} \mathrm{C}$. The incessant warming for over a century has led to the western 
Indian Ocean SSTs reaching the high SST values $\left(28.0^{\circ} \mathrm{C}\right)$ observed over the warm pool regions (Fig.1c). During 1901-2012, western Indian Ocean experienced anomalous warming of up to $1.2^{\circ} \mathrm{C}$, while the warm-pool warming was constrained to $0.7^{\circ} \mathrm{C}$. This results in a $0.5^{\circ} \mathrm{C}$ difference in the warming, which is significant with respect to the Indian Ocean SSTs, and in turn the monsoon dynamics (Izumo et al. 2008; Yang et al. 2007). Apart from nullifying the zonal SST gradient and changing the monsoon circulation, an SST increase from $26.5^{\circ} \mathrm{C}$ to $28.0^{\circ} \mathrm{C}$ will also drastically change the convective response from shallow to deep convection (Gadgil et al. 1984; Roxy 2013; Roxy et al. 2012). The sustained warming mean SSTs (Fig.1d).

Similar to other regions over the global oceans, anthropogenic forcing might be a major contributor to the observed warming over the Indian Ocean. However, the historical climate model simulations under CMIP5 using observed greenhouse gases forcing does not reproduce the zonal SST gradient, or the pronounced warming over the western Indian Ocean correlation over the western Indian Ocean (Fig.3a). Time series of these anomalies constructed over the east Pacific $\left(120-80^{\circ} \mathrm{W}, 5^{\circ} \mathrm{S}-5^{\circ} \mathrm{N}\right)$ and the western Indian Ocean yield a 
ENSO dominates the western tropical Indian Ocean variability during boreal summer through fast atmospheric teleconnections.

It is striking to notice that the number and intensity of El Niño events have significantly increased during the latter half of $20^{\text {th }}$ century (12 events), in comparison with the former half (7 events). During recent decades, SST skewness exhibits more positive values in the eastern Pacific reflecting the fact that amplitude and frequency of El Niño events have increased (Figs.3b and 4). The rate of Indian Ocean warming has also increased during the last five decades, which saw some of the strongest El Niños during the past century (Fig.3b). It is however noted that the Indian Ocean SST anomalies associated with the La Niñas are relatively smaller in comparison with those associated with the El Niños. One of the interesting facts is that, post-1950, a few warm events over the Indian Ocean have attained the threshold value for El Niño $\left(1 \sigma=0.77^{\circ} \mathrm{C}\right.$, Fig.3b). This places these warm events almost on par with the El Niños in magnitude, although the peaks are not as high.

In order to ascertain whether the increasing number of warm events may contribute to the long-term warming trend, the skewness of the east Pacific detrended SST anomalies is contrasted along with the trend of the western Indian Ocean SST anomalies (Fig.4c). The asymmetry between warm and cold events over east Pacific, with a skewness towards warm events throughout the time period is evident. This positive skewness of eastern Pacific SSTs is well correlated with the warming trend observed over the western Indian Ocean (Fig.4c, $r=0.76$ for annual values, significant at $99 \%$ confidence level).

The asymmetry in ENSO forcing is substantiated by comparing the atmospheric circulation over the tropics during El Niño and La Niña years against the climatological walker circulation (Fig.5a). The El Niño composite shows an anomalous shift in the circulation over the tropics, with the ascending cell over the east Pacific and subsidence over the maritime continent, resulting in low-level easterly anomalies over the western Indian 
Ocean (Fig.5b). These easterly anomalies weaken the mean westerlies over the Indian Ocean, leading to the observed warming. On monthly timescale, the El Niño effect on warming during summer is simultaneous. This is different from the Indian Ocean warming during individual years, observed by other studies at 3-4 months lag (or more) after the mature phase of El Niño in winter (Du et al. 2009; Lau and Nath 2003; Xie et al. 2009). The anomalous circulation in the La Niña composite, meanwhile, does not show any significant change in the low-level winds and the vertical velocity over the Indian Ocean (Fig.5c, $20-100^{\circ} \mathrm{E}, 5^{\circ} \mathrm{S}-$ $\left.10^{\circ} \mathrm{N}\right)$. This might be a reason why the warm events over the western Indian Ocean are not interspersed by any significant cooling events despite of the ENSO variability (Fig.3b). A composite of the summer SST anomalies during El Niño and La Niña years further demonstrates this asymmetry in forcing the Indian Ocean (Figs.4d and 4e). While the El Niño composite exhibits significant warming over the western Indian Ocean, the La Niña composite does not show any significant negative anomalies over the region.

The fact that the SST anomalies do not show any long-term significant trend over the east Pacific, despite a globally warming environment and positive skewness in recent decades is intriguing (Fig.1a). Tropical Pacific variability oscillating between the warm and cool events might be a first reason. However, the fact that the Indian Ocean warming favors a faster transition from El Niño to La Niña conditions in the Pacific may also contribute significantly (Kug and Kang 2006; Luo et al. 2012). Also, a recent study shows that warming trend over the Atlantic results in La Niña like conditions over the east Pacific, through a modification of the Walker circulation (Kucharski et al. 2011). These negative feedbacks due to enhanced warming over the Indian and Atlantic Oceans might explain why there are no robust long-term trends over the east Pacific. It may however be noted that unlike the Indian Ocean, data availability is relatively sparse over the Pacific, which makes it difficult for robust assessment of long-term trends over this region (Deser et al. 2010). 
So where does all the heat go to? The results here indicate that a large share of the

heat piles up in the Indian Ocean, consistent with earlier studies (Du et al. 2009; Xie et al. 2009). Figure 6a shows the SST difference between the post and pre-1950s, and demonstrates the pronounced warming over the Indian Ocean in the recent decades. Apart from the direct radiative forcing due to increasing greenhouse gases, El Niño appears as an event through which the Pacific Ocean throws out its heat, which partially gets accumulated in the Indian Ocean. Indeed, Compo and Sardeshmukh (2010) using a decomposition of ENSO-related and ENSO-unrelated SST trends demonstrated that ENSO explains up to $40 \%$ of long-term warming trends over the global oceans. Specifically, the following two factors might be helpful in explaining the sustained warming of Indian Ocean SST anomalies. One is the asymmetry in the ENSO teleconnection, due to which El Niño induces warming over the western Indian Ocean, while the La Niña fails to induce any significant cooling. The second factor is the positive skewness in ENSO forcing during recent decades, which aggravates the warming in the recent period.

The hypothesis of ENSO forcing on the western Indian Ocean warming trend during summer is tested with sensitivity experiments using a state-of-the-art global coupled oceanatmosphere model with a realistic ENSO variability (Fig.S2). Numerical simulations are compared for a tropical Pacific in which ENSO variability is suppressed, against a Pacific where ENSO variations are free to evolve. Figure $6 \mathrm{~b}$ shows the SST anomalies over the Indian Ocean due to ENSO variability in the simulations. During boreal summer, the SST anomalies show a significant warming over the western Indian Ocean. Despite of the fact that our coupled model has difficulties in representing the positive skewness associated with ENSO (Fig.S3), it is found that El Niño events have a stronger impact in warming, than La Niña events in cooling the Indian Ocean. The model experiment brings out an interesting fact-that the long-term warming over the western Indian Ocean, though at magnitudes lower 
than those observed, may exist even without increasing greenhouse gases, due to a decadal modulation of the ENSO variability.

A consequence to the western Indian Ocean warming and ENSO is probably a tendency towards more Indian Ocean Dipole (IOD) events during recent decades. IOD events manifest as patterns of anomalously warm SST in the western Indian Ocean, along with cool SST in the southeast Indian Ocean (Murtugudde et al. 1998; Saji et al. 1999; Webster et al. 1999). These dipole events tend to develop during the months of June-August and peak during September-November. Positive IOD events generally coincide with El Niños or El Niño-like events (Roxy et al. 2011). In fact, the SST anomalies over the Indian Ocean in Figure $3 \mathrm{a}$ is indicative of an IOD like response to the ENSO at the interannual time scale, but our trend analysis of the observations and model simulations do not corroborate the hypothesis that the western Indian Ocean warming is tightly linked to IOD frequency changes (Fig.6). Besides ENSO, other drivers such as the Asian monsoon variability can also trigger IOD events (Ashok et al. 2003; Cai et al. 2013). The focus of the current study is not to separate and examine the IOD events due to ENSO and other drivers, but to address whether the increasing warm events and the long-term trend over the western Indian Ocean are a consequence of the El Niños.

\section{Summary and Discussion}

Recent studies have pointed out an increased warming over the Indian Ocean warm pool, during the past half century. The current study, using SST trends computed over the past century indicates a long-term warming trend over the western Indian Ocean, which surpasses that over the warm pool, in both magnitude and period (Fig.1c). The results from the study point out the asymmetry in the ENSO teleconnection as one of the reasons, whereby El Niño events induce anomalous warming over the western Indian Ocean and La Niña events fail to 
do the inverse. A second, prominent reason is the positive SST skewness associated with ENSO, as the frequency of El Niño events have increased during recent decades.

The IPCC Fifth Assessment Report (AR5) points out that $90 \%$ of the heat due to the global warming during the last four decades has been accumulated in the oceans (IPCC 2013). The periodic occurrence of El Niño acts as a vent to exchange this heat from the ocean to the atmosphere. It is this heat that is partially transferred to the Indian Ocean via a modified Walker circulation, and is reflected in the warming trend over the region. It is interesting to note that the warming trend over the Indian Ocean is a major contributor, and largely in phase with the overall trend in the global mean SST (Fig.7). Though the frequency of El Niño events has increased in the recent decades, a strong warm event has not been recorded since 1997-98 (Fig.3b), and correspondingly the Pacific and Indian Ocean SST anomalies show a slight dampening (Figs.1c). This could add up as a reason for the recent hiatus in the global surface warming (Kosaka and Xie 2013). Again, the recent cool conditions over the east Pacific might be due to the feedback from a warmer Indian Ocean, bringing the sequence of events to a vicious cycle, which requires further extensive research. As noted by several other studies (Kucharski et al. 2011; Kug and Kang 2006; Luo et al. 2012), the warming trends over the Indian and Atlantic Oceans lead to La Niña like conditions over the Pacific.

In the recent decades, anomalous warm events, though of weaker amplitude, have occasionally shown prominence over the central Pacific (El Niño Modoki; Ashok and Yamagata 2009) and even the whole Pacific basin (Ashok et al. 2012), and the dynamics of the Indian Ocean warming may reflect these changes as well. It was noted earlier that, post1950, the warm summer SSTs over the western Indian Ocean have occasionally attained the El Niño threshold value $\left(0.77^{\circ} \mathrm{C}\right)$. Supplementing the long-term persistence of these events, 
the warming scenario over the Indian Ocean and related climate dynamics is a factor to be vigilant of, while assessing long-term climate change and variability.

\section{Acknowledgments}

Authors acknowledge the financial support by Ministry of Earth Sciences, Govt. of India, to conduct this research under Monsoon Mission (Grant \#MM/SERP/CNRS/2013/INT-10/002). We acknowledge the climate modeling groups, the Program for Climate Model Diagnosis and Intercomparison, and the World Climate Research Programme's working Group on coupled modelling, for their roles in making available the "CMIP5" multi-model data sets.

\section{References}

Alory, G., S. Wijffels, and G. Meyers, 2007: Observed temperature trends in the Indian Ocean over 1960-1999 and associated mechanisms. Geophysical Research Letters, 34.

Annamalai, H., S. P. Xie, J. P. McCreary, and R. Murtugudde, 2005: Impact of Indian Ocean sea surface temperature on developing El Nino. Journal of Climate, 18, 302-319.

Ashok, K., and T. Yamagata, 2009: The El Nino with a difference. Nature, 461.

Ashok, K., Z. Guan, and T. Yamagata, 2003: A look at the relationship between the ENSO and the Indian Ocean dipole. Journal of the Meteorological Society of Japan, 81, 41-56.

Ashok, K., T. Sabin, P. Swapna, and R. Murtugudde, 2012: Is a global warming signature emerging in the tropical Pacific? Geophysical Research Letters, 39.

Behrenfeld, M. J., and Coauthors, 2006: Climate-driven trends in contemporary ocean productivity. Nature, 444, 752-755.

Cadet, D. L., 1985: The southern oscillation over the Indian Ocean. Journal of climatology, 5, 189-212.

Cai, W., and Coauthors, 2013: Projected response of the Indian Ocean Dipole to greenhouse warming. Nature geoscience, 6, 999-1007. 
275 Chambers, D., B. Tapley, and R. Stewart, 1999: Anomalous warming in the Indian Ocean 276 coincident with El Niño. Journal of Geophysical Research: Oceans (1978-2012), 104, 30352773047.

278 Compo, G. P., and P. D. Sardeshmukh, 2010: Removing ENSO-related variations from the 279 climate record. Journal of Climate, 23, 1957-1978.

280 Dee, D., and Coauthors, 2011: The ERA - Interim reanalysis: Configuration and performance of the data assimilation system. Quarterly Journal of the Royal Meteorological Society, 137, 553-597.

Deser, C., M. A. Alexander, S. P. Xie, and A. S. Phillips, 2010: Sea surface temperature 284 variability: Patterns and mechanisms. Annual review of marine science, 2, 115-143.

Dong, L., T. Zhou, and B. Wu, 2014: Indian Ocean warming during 1958-2004 simulated by a climate system model and its mechanism. Climate Dynamics, 42, 203-217.

Du, Y., and S. P. Xie, 2008: Role of atmospheric adjustments in the tropical Indian Ocean warming during the 20th century in climate models. Geophysical Research Letters, 35.

Du, Y., S.-P. Xie, G. Huang, and K. Hu, 2009: Role of Air-Sea Interaction in the Long 290 Persistence of El Niño-Induced North Indian Ocean Warming. Journal of Climate, 22, 2023291 2038 .

Gadgil, S., N. V. Joshi, and P. V. Joseph, 1984: Ocean-atmosphere coupling over monsoon regions. Nature, 312, 141-143.

IPCC, 2013: IPCC WGI Fifth Assessment Report, Chapter 3 - Observations: Ocean.

Izumo, T., C. D. Montegut, J. J. Luo, S. K. Behera, S. Masson, and T. Yamagata, 2008: The Role of the Western Arabian Sea Upwelling in Indian Monsoon Rainfall Variability. Journal of Climate, 21, 5603-5623.

Klein, S. A., B. J. Soden, and N.-C. Lau, 1999: Remote sea surface temperature variations during ENSO: Evidence for a tropical atmospheric bridge. Journal of Climate, 12, 917-932.

Kosaka, Y., and S.-P. Xie, 2013: Recent global-warming hiatus tied to equatorial Pacific surface cooling. Nature, 501, 403-407. 
Kucharski, F., I. S. Kang, R. Farneti, and L. Feudale, 2011: Tropical Pacific response to 20th century Atlantic warming. Geophysical Research Letters, 38.

Kug, J.-S., and I.-S. Kang, 2006: Interactive feedback between ENSO and the Indian Ocean. Journal of climate, 19, 1784-1801.

Lau, N. C., and M. J. Nath, 2003: Atmosphere-ocean variations in the Indo-Pacific sector during ENSO episodes. Journal of Climate, 16, 3-20.

Luo, J.-J., W. Sasaki, and Y. Masumoto, 2012: Indian Ocean warming modulates Pacific climate change. Proceedings of the National Academy of Sciences, 109, 18701-18706.

Masson, S., P. Terray, G. Madec, J. J. Luo, T. Yamagata, and K. Takahashi, 2012: Impact of intra-daily SST variability on ENSO characteristics in a coupled model. Climate Dynamics, $1-27$.

Murtugudde, R., B. Goswami, and A. Busalacchi, 1998: Air-sea interaction in the southern tropical Indian Ocean and its relations to interannual variability of the monsoon over India. Proceedings of the International conference on monsoon and hydrologic cycle, 184-188.

Murtugudde, R., J. P. McCreary, and A. J. Busalacchi, 2000: Oceanic processes associated with anomalous events in the Indian Ocean with relevance to 1997-1998. Journal of Geophysical Research: Oceans (1978-2012), 105, 3295-3306.

Nicholson, S. E., 1997: An analysis of the ENSO signal in the tropical Atlantic and western Indian Oceans. International Journal of Climatology, 17, 345-375.

Rao, S. A., A. R. Dhakate, S. K. Saha, S. Mahapatra, H. S. Chaudhari, S. Pokhrel, and S. K. Sahu, 2012: Why is Indian Ocean warming consistently? Climatic change, 110, 709-719.

Rayner, N., and Coauthors, 2003: Global analyses of sea surface temperature, sea ice, and night marine air temperature since the late nineteenth century. J. Geophys. Res, 108, 4407.

Roxy, M., 2013: Sensitivity of precipitation to sea surface temperature over the tropical summer monsoon region — and its quantification. Climate Dynamics, 1-11.

Roxy, M., S. Gualdi, H.-K. Drbohlav, and A. Navarra, 2011: Seasonality in the relationship between El Nino and Indian Ocean dipole. Climate Dynamics, 37, 221-236. 
Roxy, M., Y. Tanimoto, B. Preethi, T. Pascal, and R. Krishnan, 2012: Intraseasonal SSTprecipitation relationship and its spatial variability over the tropical summer monsoon region. Climate Dynamics, 41, 45-61.

Ryther, J., and D. Menzel, 1965: On the production, composition, and distribution of organic matter in the Western Arabian Sea. Elsevier, 199-209.

Saji, N. H., B. N. Goswami, P. N. Vinayachandran, and T. Yamagata, 1999: A dipole mode in the tropical Indian Ocean. Nature, 401, 360-363.

Smith, T. M., R. W. Reynolds, T. C. Peterson, and J. Lawrimore, 2008: Improvements to NOAA's historical merged land-ocean surface temperature analysis (1880-2006). Journal of Climate, 21, 2283-2296.

Swapna, P., R. Krishnan, and J. Wallace, 2013: Indian Ocean and monsoon coupled interactions in a warming environment. Climate Dynamics, 1-16.

Taylor, K. E., R. J. Stouffer, and G. A. Meehl, 2012: An Overview of CMIP5 and the Experiment Design. Bulletin of the American Meteorological Society, 93.

Terray, P., K. Kamala, S. Masson, G. Madec, A. Sahai, J. J. Luo, and T. Yamagata, 2011: The role of the intra-daily SST variability in the Indian monsoon variability and monsoonENSO-IOD relationships in a global coupled model. Climate Dynamics, 1, 647.

Tourre, Y. M., and W. B. White, 1995: ENSO signals in global upper-ocean temperature. Journal of Physical Oceanography, 25, 1317-1332.

Webster, P. J., A. M. Moore, J. P. Loschnigg, and R. R. Leben, 1999: Coupled oceanatmosphere dynamics in the Indian Ocean during 1997-98. Nature, 401, 356-360.

Xie, S.-P., H. Annamalai, F. A. Schott, and J. P. McCreary, 2002: Structure and mechanisms of South Indian Ocean climate variability. Journal of Climate, 15, 864-878.

Xie, S.-P., K. Hu, J. Hafner, H. Tokinaga, Y. Du, G. Huang, and T. Sampe, 2009: Indian Ocean capacitor effect on Indo-western Pacific climate during the summer following El Niño. Journal of Climate, 22, 730-747. 
355 Yang, J., Q. Liu, S. P. Xie, Z. Liu, and L. Wu, 2007: Impact of the Indian Ocean SST basin 356 mode on the Asian summer monsoon. Geophysical Research Letters, 34.

357 Yu, L., and M. M. Rienecker, 1999: Mechanisms for the Indian Ocean warming during the 358 1997-98 El Nino. Geophysical Research Letters, 26, 735-738. 


\section{Figure Captions}

Figure 1. (a) Observed trend in mean summer (June-Sept) SST $\left({ }^{\circ} \mathrm{C}\right.$ per year) over the global tropics during 1901-2012. (b) Interannual standard deviation of SST $\left({ }^{\circ} \mathrm{C}\right)$ for the same domain and time period. Time series of mean (c) summer and (d) annual SST $\left({ }^{\circ} \mathrm{C}\right)$ over the western Indian Ocean (WIO, red, $\left.50-65^{\circ} \mathrm{E}, 5^{\circ} \mathrm{S}-10^{\circ} \mathrm{N}\right)$ and rest of the Indian Ocean (RIO, black, $70-100^{\circ} \mathrm{E}$, $20^{\circ} \mathrm{S}-20^{\circ} \mathrm{N}$ ). WIO and RIO are marked with dashed rectangles in $\boldsymbol{a}$. The CMIP5 ensemble means based on 25 climate models, averaged over the WIO (light red) and RIO (light grey), are also displayed in $\boldsymbol{c}$.

Figure 2. Observed mean summer (June-Sept) SST $\left({ }^{\circ} \mathrm{C}\right)$ over the Indian Ocean. Warm pool region in the text refers to the highlighted region with SST $>28^{\circ} \mathrm{C}$.

Figure 3. (a) Observed correlation between mean summer (June-Sept) SSTs $\left({ }^{\circ} \mathrm{C}\right)$ over the east Pacific $\left(120-80^{\circ} \mathrm{W}, 5^{\circ} \mathrm{S}-5^{\circ} \mathrm{N}\right)$ and the global tropics during 1901-2012. Correlation coefficients have been computed from detrended data. Contours denote regions significant at the $99 \%$ confidence level. (b) Time series of mean summer SST anomalies $\left({ }^{\circ} \mathrm{C}\right)$ over the east Pacific (red) and the western Indian Ocean (green). Both time series have been detrended. East Pacific SST anomalies, which rise above 1 standard deviation $\left(0.77^{\circ} \mathrm{C}\right.$, horizontal dashed line) are considered as El Niño events.

Figure 4. SST skewness estimated for detrended monthly SST anomalies during the periods (a) 19011950 and (b) 1951-2012. Contours denote regions significant at the 99\% confidence level. (c) Time series of skewness computed from detrended SST anomalies over the east Pacific (red) and of SST trend (green) over the WIO estimated over 31-year sliding periods, for the northern summer. The two time series have also been smoothed with a 31-year moving average for display only. The annual values of the two time series are significantly correlated $(r=0.76)$, at $99 \%$ confidence level.

Figure 5. Zonal atmospheric circulation for boreal summer over the equator $\left(5^{\circ} \mathrm{S}-10^{\circ} \mathrm{N}\right)$ during $(\mathbf{a})$ climatological mean conditions, and anomalies during (b) El Niño years, and (c) La Niña years. The winds (vectors, unit $\mathrm{m} \mathrm{s}^{-1}$ ) and the vertical velocity (colors, unit $\mathrm{Pa} \mathrm{s}^{-1}$ ) indicate the 
zonal and vertical motion (positive upward) of air, respectively. Similarly, SST $\left({ }^{\circ} \mathrm{C}\right)$ during (d) climatological mean conditions, and anomalies during (e) El Niño years, and (f) La Niña years. The composites are estimated from detrended monthly SST anomalies.

Figure 6. (a) Difference in the SST $\left({ }^{\circ} \mathrm{C}\right)$ over the Indian Ocean, for the periods 1951-2012 and 19011950, for the northern summer. (b) Model simulated mean SST anomalies $\left({ }^{\circ} \mathrm{C}\right)$ during northern summer, in response to ENSO variability in the model. The model simulated SST 
(a) SST trend $\left[{ }^{\circ} \mathrm{C}\right.$ per year], June-Sept mean

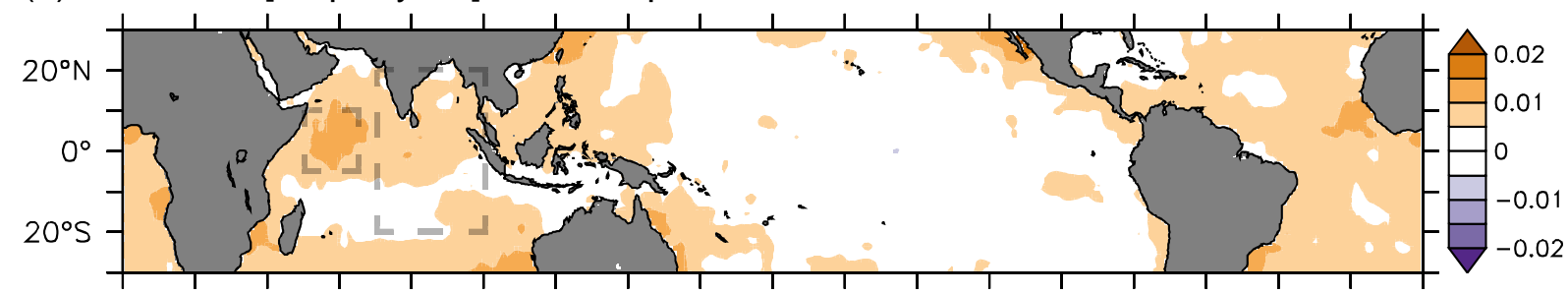

(b) SST standard deviations $\left[{ }^{\circ} \mathrm{C}\right]$, June-Sept mean

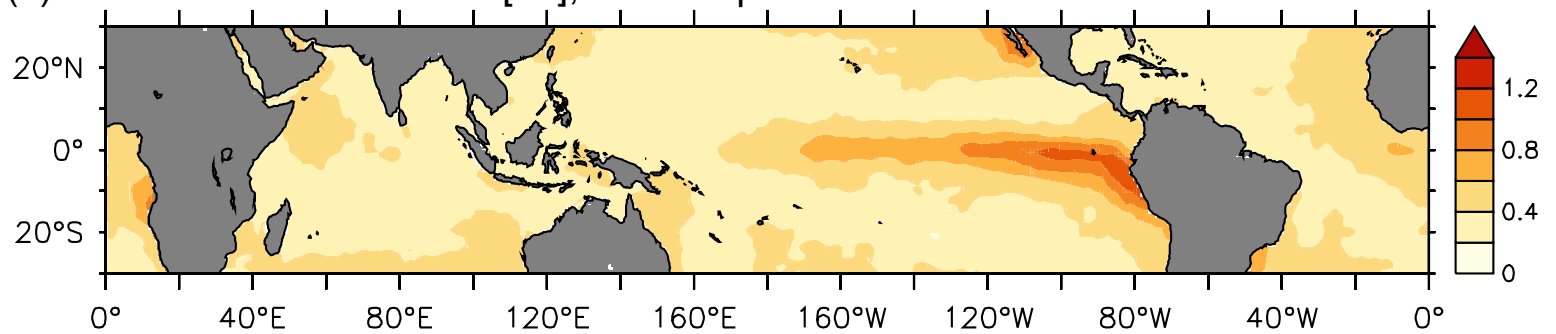

(c) SST [ $\left.{ }^{\circ} \mathrm{C}\right]$ : WIO vs RIO, June-Sept mean

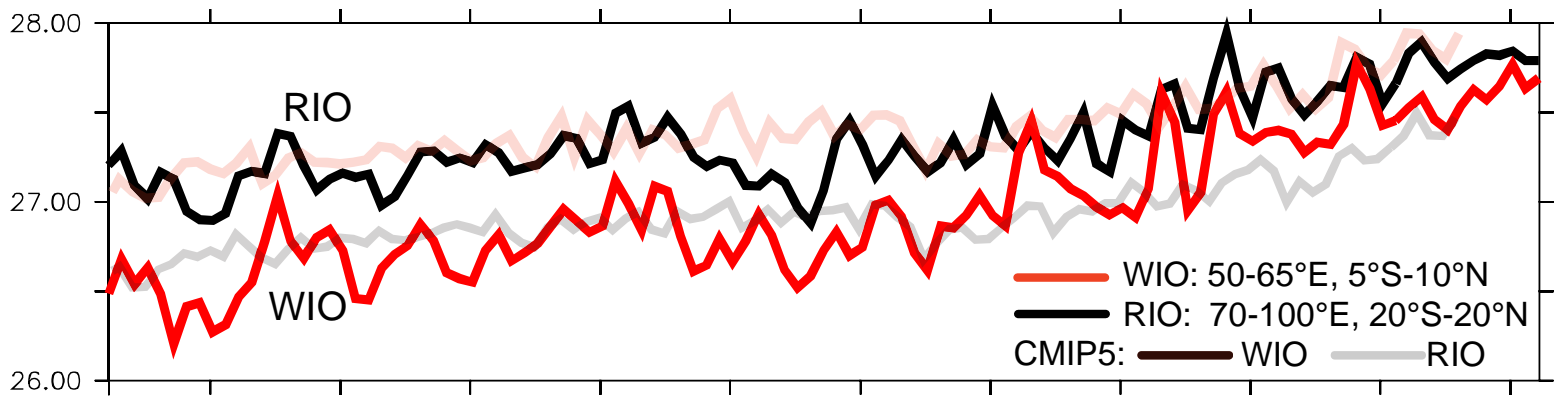

(d) $\mathrm{SST}\left[{ }^{\circ} \mathrm{C}\right]$ : WIO vs RIO, Annual mean

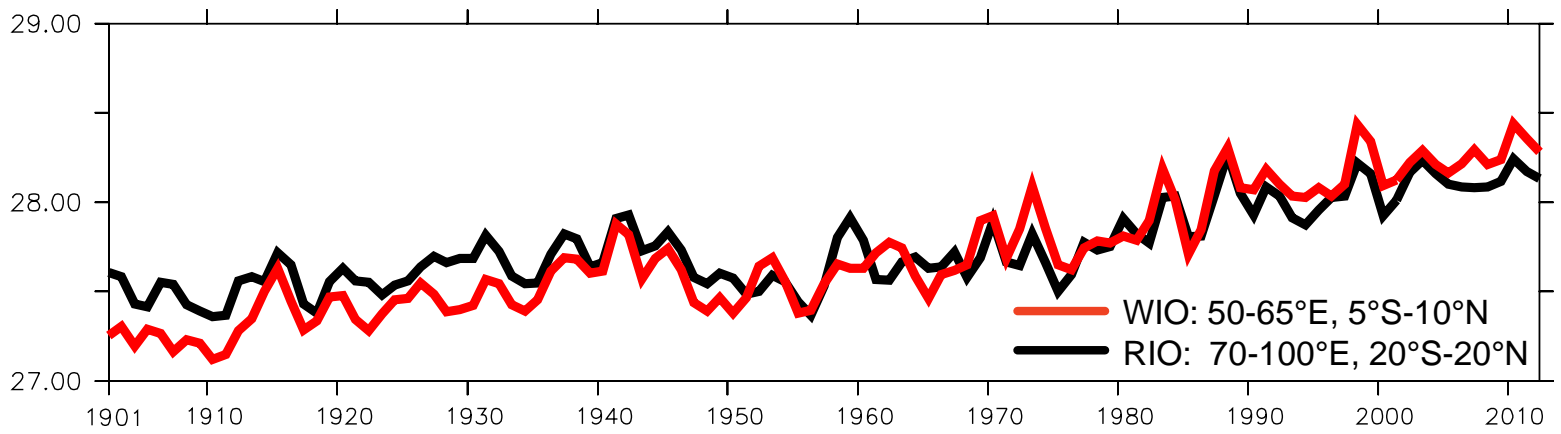

Figure 1. (a) Observed trend in mean summer (June-Sept) SST $\left({ }^{\circ} \mathrm{C}\right.$ per year) over the global tropics during 1901-2012. (b) Interannual standard deviation of SST $\left({ }^{\circ} \mathrm{C}\right)$ for the same domain and time period. Time series of mean (c) summer and (d) annual SST $\left({ }^{\circ} \mathrm{C}\right)$ over the western Indian Ocean (WIO, red, $50-65^{\circ} \mathrm{E}, 5^{\circ} \mathrm{S}-10^{\circ} \mathrm{N}$ ) and rest of the Indian Ocean (RIO, black, $70-100^{\circ} \mathrm{E}, 20^{\circ} \mathrm{S}-20^{\circ} \mathrm{N}$ ). WIO and RIO are marked with dashed rectangles in $\boldsymbol{a}$. The CMIP5 ensemble means based on 25 climate models, averaged over the WIO (light red) and RIO (light grey), are also displayed in $\boldsymbol{c}$. 


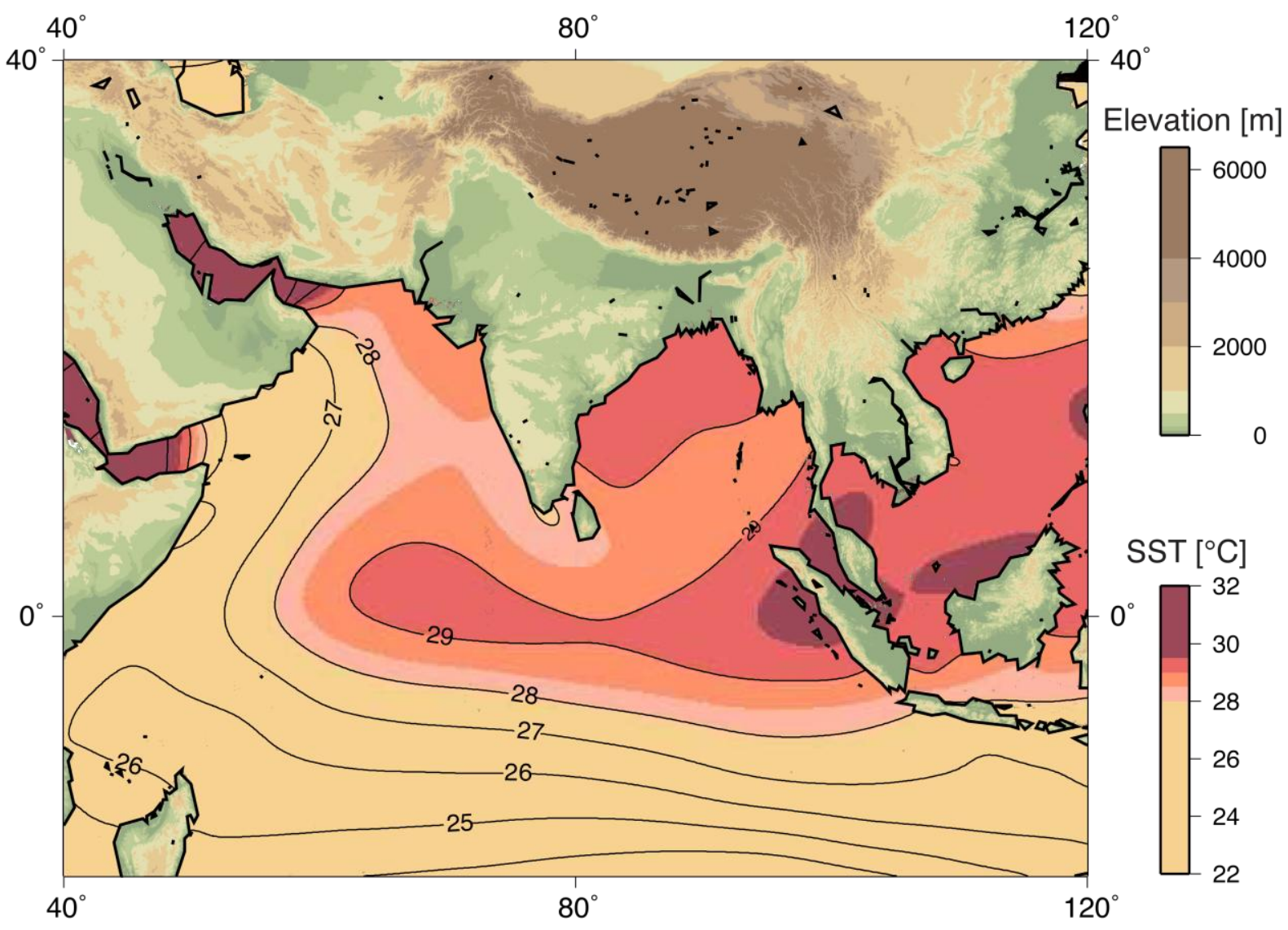

Figure 2. Observed mean summer (June-Sept) SST $\left({ }^{\circ} \mathrm{C}\right)$ over the Indian Ocean. Warm pool region in 410 the text refers to the highlighted region with SST $>28^{\circ} \mathrm{C}$. 
(a) Correlation: east Pacific SSTa vs Global SSTa, June-Sept mean

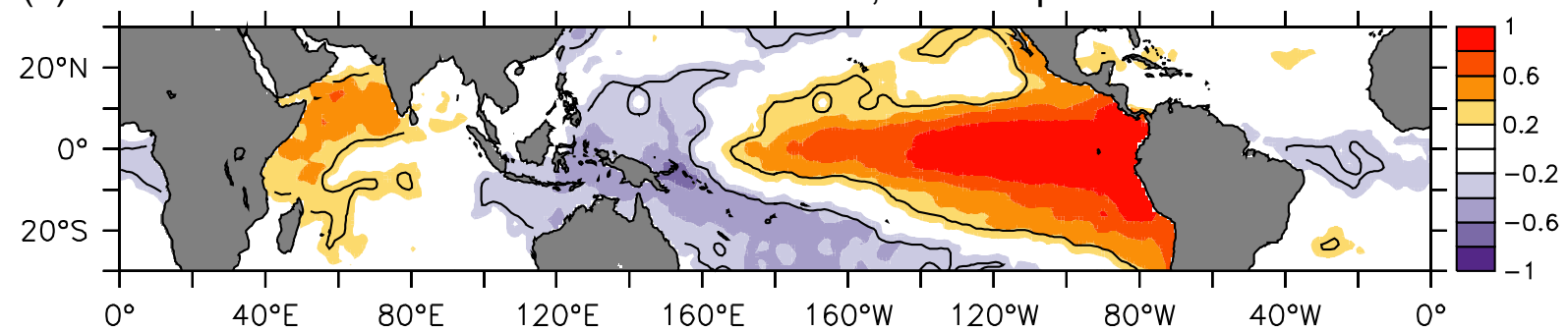

(b) SST anomalies [ $\left.{ }^{\circ} \mathrm{C}\right]$ : east Pacific vs WIO, June-Sept mean

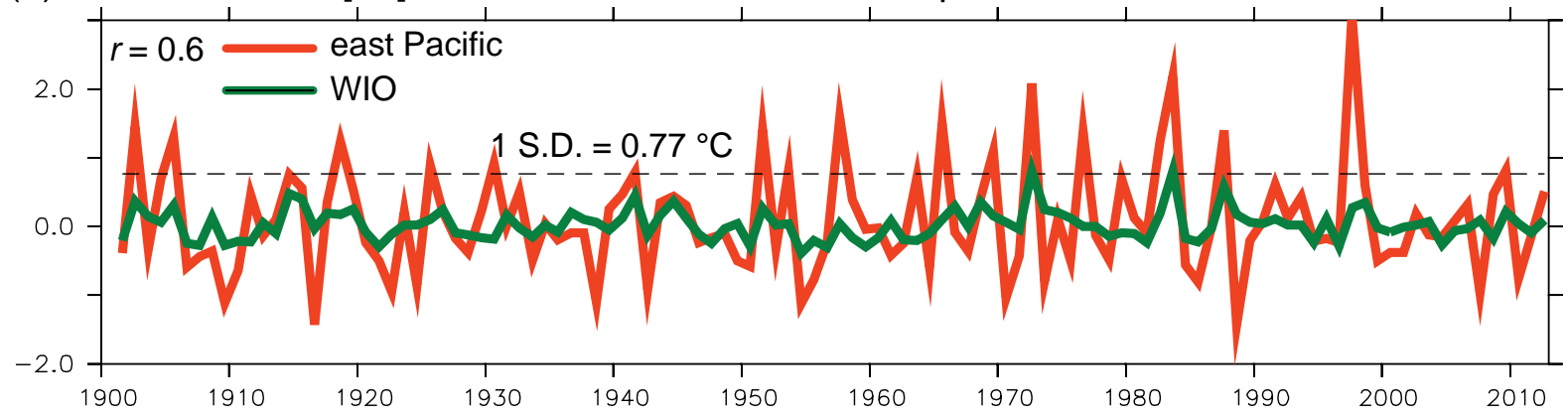

Figure 3. (a) Observed correlation between mean summer (June-Sept) SSTs $\left({ }^{\circ} \mathrm{C}\right.$ ) over the east Pacific $\left(120-80^{\circ} \mathrm{W}, 5^{\circ} \mathrm{S}-5^{\circ} \mathrm{N}\right)$ and the global tropics during 1901-2012. Correlation coefficients have been computed from detrended data. Contours denote regions significant at the $99 \%$ confidence level. (b) Time series of mean summer SST anomalies $\left({ }^{\circ} \mathrm{C}\right)$ over the east Pacific $(r e d)$ and the western Indian Ocean (green). Both time series have been detrended. East Pacific SST anomalies, which rise above 1 standard deviation $\left(0.77^{\circ} \mathrm{C}\right.$, horizontal dashed line $)$ are considered as El Niño events. 
(a) SST Skewness [1901-1950]

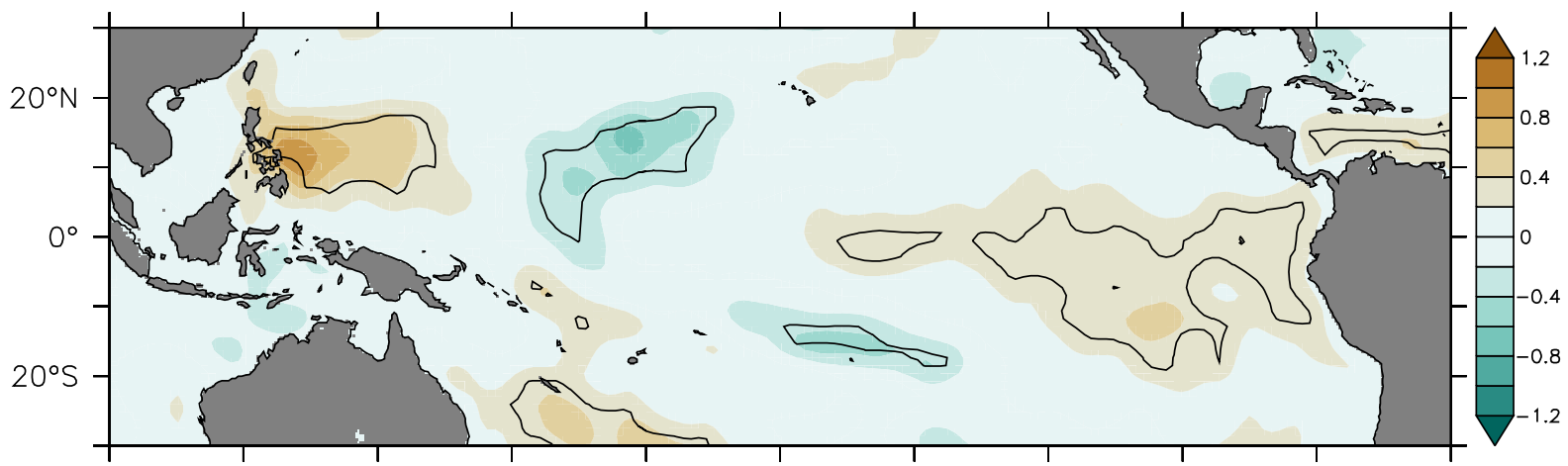

(b) SST Skewness [1951-2012]

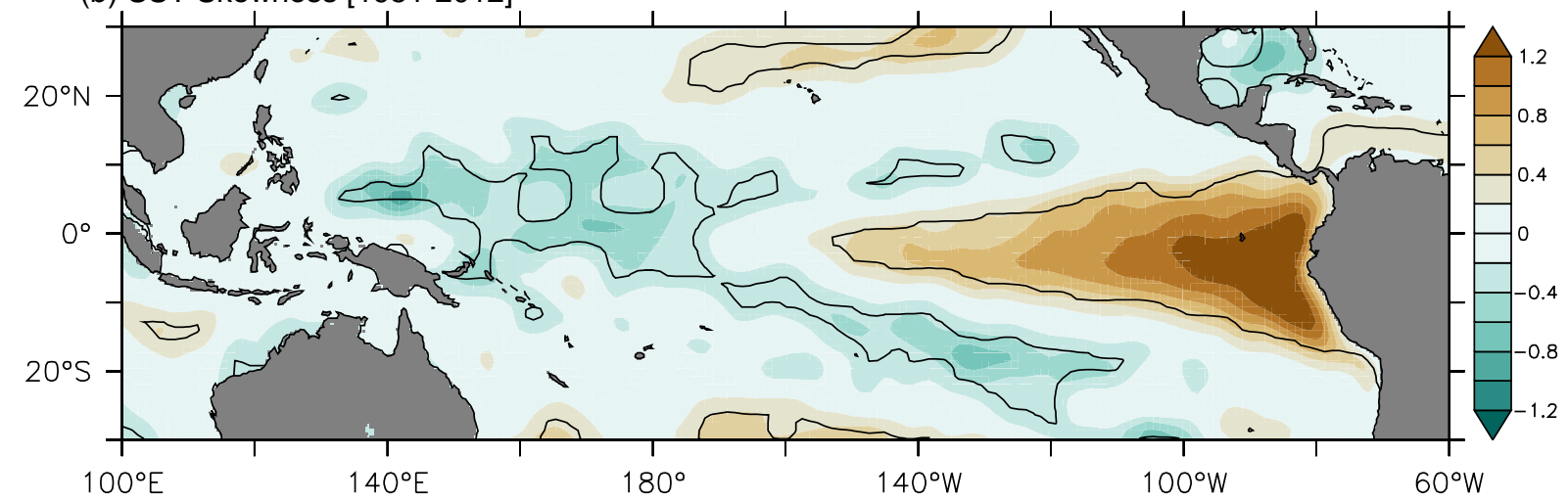

(c) Skewness [east Pacific] and trend [WIO]: SST anomalies

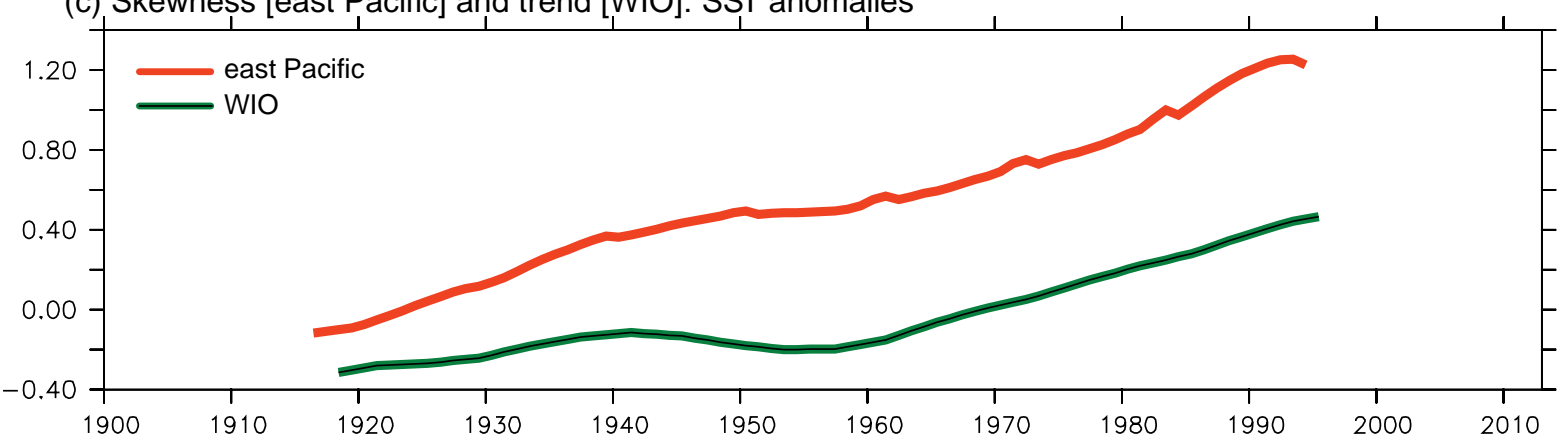

Figure 4. SST skewness estimated for detrended monthly SST anomalies during the periods (a) 19011950 and (b) 1951-2012. Contours denote regions significant at the 99\% confidence level. (c) Time series of skewness computed from detrended SST anomalies over the east Pacific (red) and of SST trend (green) over the WIO estimated over 31-year sliding periods, for the northern summer. The two time series have also been smoothed with a 31-year moving average for display only. The annual values of the two time series are significantly correlated $(r=0.76)$, at $99 \%$ confidence level. 
(a) Mean Walker circulation

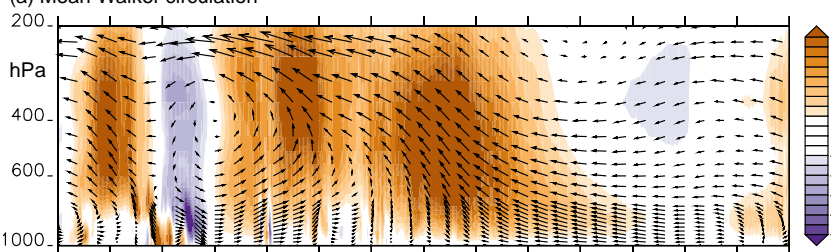

(b) El Nino Composite - Walker circulation anomalies
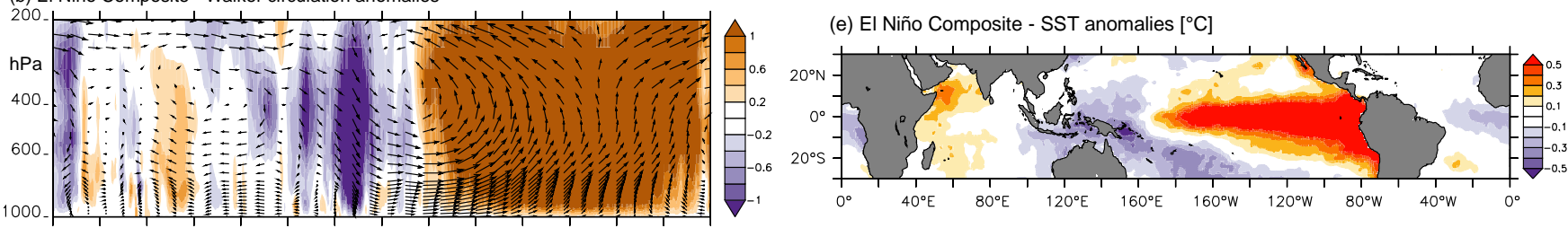

(c) La Nina Composite - Walker circulation anomalies

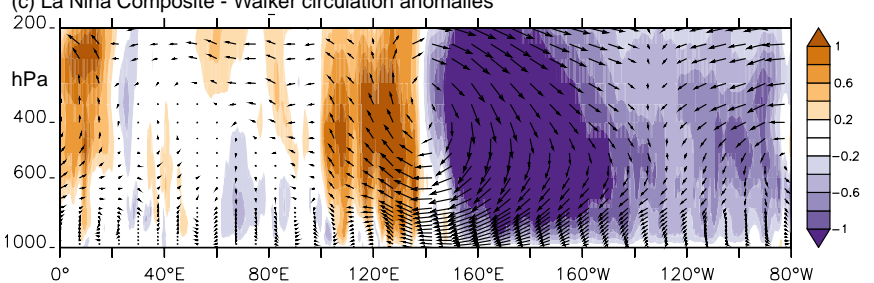

(d) Climatological mean SST $\left[{ }^{\circ} \mathrm{C}\right]$

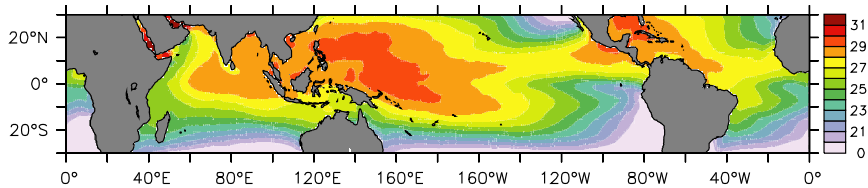

(f) La Niña Composite - SST anomalies $\left[{ }^{\circ} \mathrm{C}\right]$

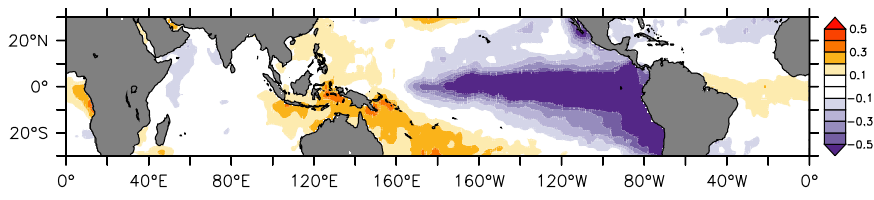

Figure 5. Zonal atmospheric circulation for boreal summer over the equator $\left(5^{\circ} \mathrm{S}-10^{\circ} \mathrm{N}\right)$ during (a) climatological mean conditions, and anomalies during (b) El Niño years, and (c) La Niña years. The winds (vectors, unit $\mathrm{m} \mathrm{s}^{-1}$ ) and the vertical velocity (colors, unit $\mathrm{Pa} \mathrm{s}^{-1}$ ) indicate the zonal and vertical motion (positive upward) of air, respectively. Similarly, SST $\left({ }^{\circ} \mathrm{C}\right)$ during $(\mathbf{d})$ climatological mean conditions, and anomalies during (e) El Niño years, and (f) La Niña years. The composites are estimated from detrended monthly SST anomalies. 
(a) SST Difference between [1951-2012] and [1901-1950]

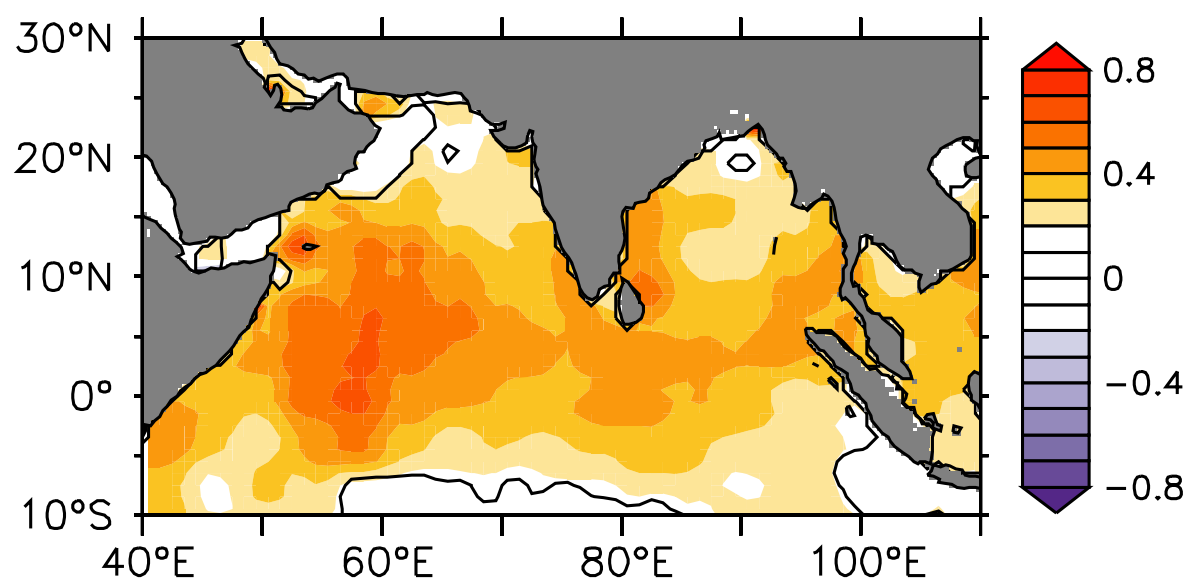

(b) SST Difference between [ENSOvar] and [noENSOvar]

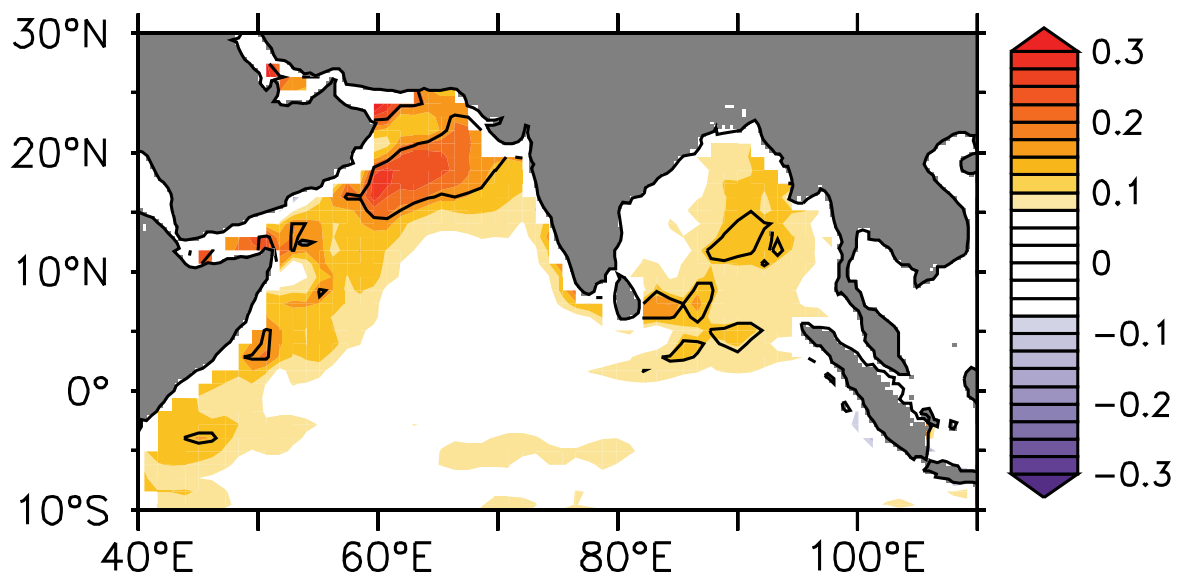

433 Figure 6. (a) Difference in the SST $\left({ }^{\circ} \mathrm{C}\right)$ over the Indian Ocean, for the periods 1951-2012 and 1901434 1950, for the northern summer. (b) Model simulated mean SST anomalies $\left({ }^{\circ} \mathrm{C}\right)$ during northern 435 summer, in response to ENSO variability in the model. The model simulated SST variability due to 436 ENSO is estimated from the SST anomalies in the control run (ENSOvar). These SST anomalies are 437 defined with respect to a monthly climatology computed from the sensitivity experiment without 438 ENSO variability (noENSOvar). $\boldsymbol{a}$ denotes the role of ENSO-skewness and $\boldsymbol{b}$ that of ENSO439 asymmetry, on the Indian Ocean. Contours denote regions significant at the $99 \%$ confidence level 440 estimated from a resampling method. 


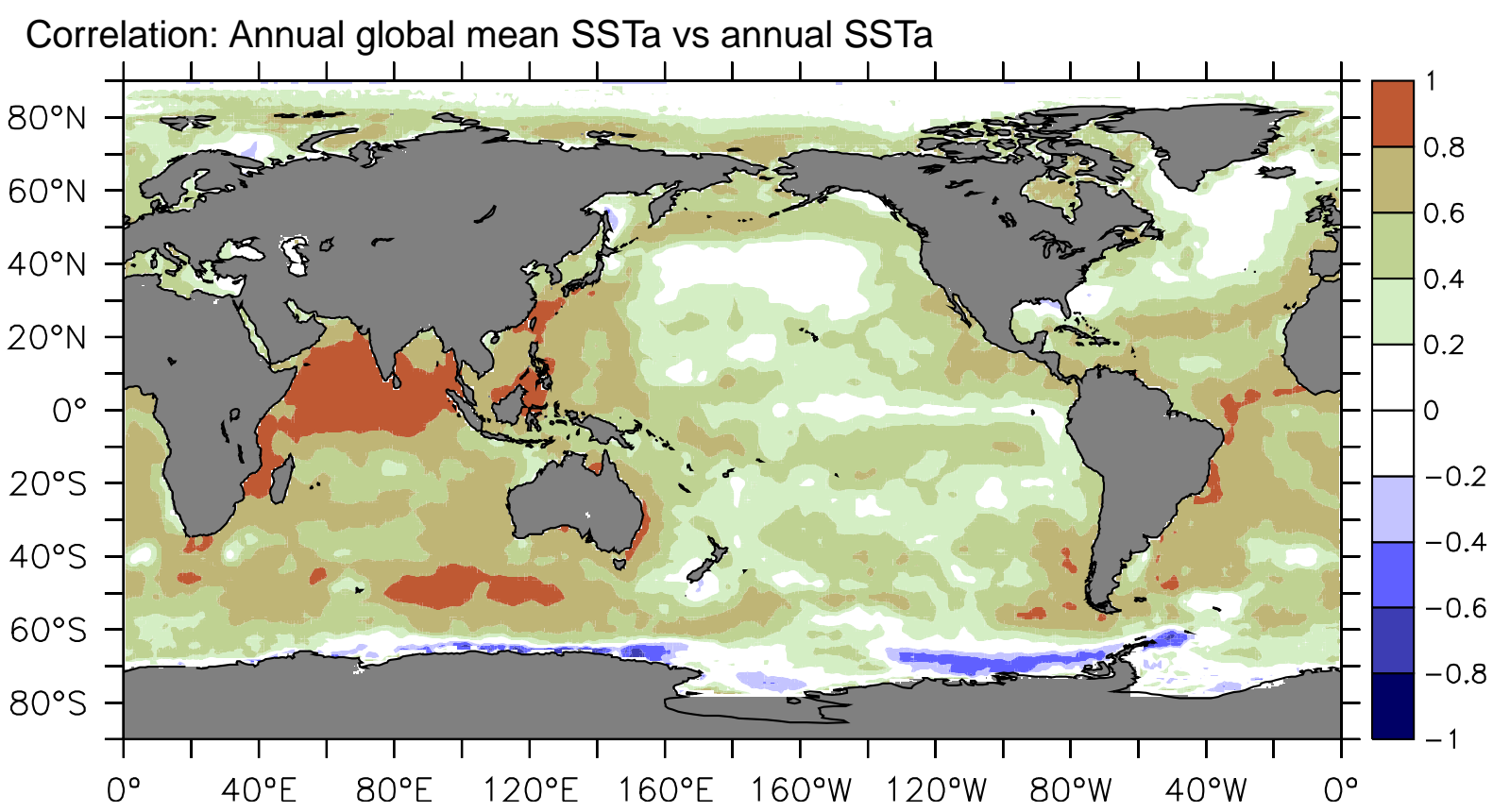

442 Figure 7. Observed correlation between annual global mean SST and the annual SST at each grid, 443 during 1901-2012. Color shading denotes correlation coefficients significant at the 99\% confidence 444 level. 